\title{
DIE STRUKTURELE KOMPOSISIE VAN DIE PROLOOG VAN DIE JOHANNESEVANGELIE HEROORWEEG
}

\author{
J G VAN DER WATT
}

\section{ABSTRACT}

The structural composition of the Johannine Prologue reconsidered

A brief summary of several efforts to describe the structure of the Prologue is followed by a suggestion that the Prologue consists of two parts. Each part is individually structured according to its own structuring principle. These two parts are again structurally linked in order to illustrate their interdependence in transmitting the message of the pre-incarnative Logos who became flesh so that we might share in God's grace.

\section{Inleidende opmerkings}

In die ondersoek van die Johannesevangelie is daar enkele gedeeltes wat vergelyk kan word met die spreekwoordelike skoenlapper wat sy bewonderaar dieper en dieper die woud inlei - 'n bewonderaar wat bewus is van die gevare van die woud, maar nogtans nie kan ontkom aan die betowering van die skoenlapper nie. So 'n gedeelte is die proloog. Word die literatuur van die Johannesevangelie nagegaan, tree die belang van die diskussie rondom die problematiek rakende die proloog (op alle terreine, bv. uitleg, struktuur, voorgeskiedenis ens.) al hoe sterker na vore;" 'n problematiek met 'n diepte wat helaas steeds die volle "begripsgreep" van eksegete in ' $n$ groot mate ontsnap.

In hierdie artikel gaan die strukturele samestelling van die proloog weer in oënskou geneem word te midde van die gevaar dat die agtervolging van die skoenlapper tot nog ' $n$ verdwaalde in die woud kan lei.

2. Ter oriëntasie - enkele voorbeelde van pogings wat al aangewend is om die strukturele samestelling van die proloog te verklaar

Die volgende oorsig oor enkele van die bestaande strukturele benaderings dien bloot as kort oriëntasie. Uit die aard van die saak kan die benaderings in die bestek van 'n artikel soos dié nie volledig bespreek word nie. 


\subsection{Die proloog is chiasties opgebou.}

Culpepper se artikel $^{21}$ is ' $n$ goeie en resente voorbeeld van hierdie benadering wat in verskeie kringe steun geniet. ${ }^{3}$ ' Skematies stel hy die opbou so voor:

$A(1-2)$

$\mathrm{B}(3)$

$\mathrm{C}(4-5)$

B1 (17)

$\mathrm{D}(6-8)$

C1 (16)

$E(9-10)$

D1 (15)

$F(11)$

E1 (14)

$\mathrm{G}(12 \mathrm{a})$

F1 (13)

$H(12 b)$

Culpepper beredeneer sy saak goed, maar het tog nie daarin geslaag om al die dele ewe oortuigend met mekaar te verbind nie. As voorbeeld hiervan kan die korrespondensie of ooreenkoms wat hy tussen 1:4-5 en 16 probeer tref, dien. Hy erken dat Brown" so 'n korrespondensie "highly imaginative" noem, maar probeer tog 'n saak vir die parallelisme uitmaak deur te sê dat die parallel "not obvious" maar tog ook "not absent" is. ${ }^{5)}$ Hy vermeng op 'n selektiewe wyse getuienis uit verskeie bronne om uiteindelik genade en ewige lewe as sinonieme gelyk te kan stel, ${ }^{61}$ soos wat sy chiasme vereis. Probleme soos "korrespondensie" wat nie noodwendig sinonimiteit beteken nie en semantiese verskraling van die woorde wat te maklik gelyk gestel word ${ }^{71}$ laat tog die gedagte van struktuurdwang ontstaan. Afgesien daarvan toon Ellingworth ${ }^{8}$ byvoorbeeld aan hoe die betrokke temas op ' $n$ veel direkter en helderder wyse in ander dele van die proloog voorkom (wat natuurlik nie by Culpepper se chiasme pas nie en dus liefs verswyg moet word). Nog ' $n$ feller aanval teen ' $n$ "elaborate chiastic structure" kom van Miller" wat strukture van dié aard aan "vivid imaginations" toeskryf.

Die baba moet egter nie hier met die badwater uitgegooi word nie. Bloot die feit dat soveel (vooraanstaande) Johannesstudente die standpunt so aantreklik vind, dui aan dat die benadering nie geheel sonder meriete is nie. Die deurhaak van die knoop lê egter by die implementering daarvan. Hierby sal later aangesluit word.

\subsection{Die proloog is parallelisties opgebou}

Schmithals deel die proloog in twee parallelle gedeeltes in. ${ }^{10}$ 'Sy indeling lyk soos volg: 


\section{verse $1-5$ korrespondeer met 14 \\ verse $\quad 6-8$ korrespondeer met 15 verse $9-11$ korrespondeer met 16 verse $12 \mathrm{a}-\mathrm{b}$ korrespondeer met 17 verse $12 c-13$ korrespondeer met 18}

Hierdie formele parallelisme wys vir hom dan ook heen na ' $n$ inhoudelike parallelisme. Sonder om in detail daarop in te gaan, kan hier net genoem word dat hierdie benadering problematies is, hoofsaaklik vanweë die gebrek aan formele indelingsverbande wat die argumente rondom die aanvaarbaarheid van die sogenaamde parallelistiese struktuur arbitrêr maak.

Hoewel Du Toit in sy artikel nie konsentreer op die uiteensetting van ' $n$ volledige struktuur nie, gee hy tog ' $n$ aanduiding van sy siening in die volgende aanhaling: "The Prologue can be seen as two, to a large extent overlapping, circles with verses 1 and 14 as respective centres". ${ }^{11}$ Die belang hiervan lê $m$.i. daarin dat so gesien, die twee dele elk relatief selfstandig is maar tog in perspektief van die geheel gesien moet word (hoewel nie noodwendig parallelisties niel. Ook hierdie punt sal later opgevolg word.

\subsection{Die proloog liniêr-tematies opgebou}

Brown deel weer die proloog in strofes in wat hy tematies beskryf, byvoorbeeld 1:1-2 gaan oor die Logos met God; 1:3-5 oor die Logos en die skepping; $1: 10-12 \mathrm{~b}$ oor die Logos en die wêreld; $1: 14$ en 16 oor die aandeel van die gemeenskap aan die Logos. ${ }^{12}$ ) Hierdie verse sou dan 'n oorspronklike himne uitgemaak het waarby latere invoegings gemaak is. So ' $n$ benadering help gewoonlik nie veel met die beredenering van die (huidige) struktuur nie, bloot omdat die nagaan van die struktuur sinchroniese arbeid behels. Die belang van Brown se opmerkings vir die artikel lê daarin dat hy die aandag op die tematiese voortgang binne die proloog vestig.

\subsection{Die proloog relatief ongestruktureer}

Vir Miller bevat 1:1-5 as sodanig "a complete Logos hymn" wat inderdaad die "logical foundation-piece" vir die res van die proloog vorm. ${ }^{13 \text { ) }}$ Volgens hom is die res van die proloog nie literêr gestruktureer nie. In 1:1-5 word vier verskillende relasies waarin die Logos staan $\mathrm{nl}$. met God, met die wêreld, reddend met die mense en oorwinnend teenoor die bose) met behulp van vier tweestrofige gedeeltes beskryf. Vir die struk- 
tuur om te "werk" word 1:1c en 1:2 as onoorspronklike materiaal uit die proloog weggeneem (- dit postuleer hy sonder enige oortuigende bewyse). Hoewel Miller ook nie van die gevaar van manipulasie van materiaal t.w.v. 'n "werkbare" struktuur ontkom nie, het sy benadering tog die voordeel dat dit in sterk kontras met oordrewe strukturalisme staan. Dit skerp 'n kritiese houding teenoor onversigtige strukturalisme op.

\section{Die proloog is komplimentêr opgebou}

In hierdie artikel word die mening gehuldig dat daar binne die twee onderskeie dele van die proloog (d.w.s. vv. $1-13$ en 14-18) van verskillende struktureringsbeginsels gebruik gemaak word en dat die dele weer op ' $n$ bepaalde manier saamgebind word. ${ }^{14}$ '

Ter wille van makliker verwysing volg daar nou 'n volledige teks van die proloog (vgl. p. 72).

Ek het êrens gelees hulle sê ons kan hierdie vel Grieks gebruik.

\subsection{Die tweedeling van die proloog}

Verskeie geleerdes het al op die tweedeling van die proloog gewys, o.a. Du Toit, Giblin en in ' $n$ sekere sin Becker. ${ }^{15}$ ) Implisiet kom beide die parallelistiese en chiastiese indelings op tweedeling neer, maar dan binne 'n sterk saamgebinde geheelstruktuur.

Dit is juis die raaksien van die tweedeling wat ' $n$ belangrike sleutel bied vir die verstaan van die proloog as 'n geheel. As werkshipotese sal daar aanvanklik eers aan die eerste 13 verse aandag gegee word en daarna aan die res. Die sinvolheid en inderdaad die noodsaaklikheid van so ' $n$ indeling sal in die loop van die artikel duidelik word.

\subsection{Historiese verloop as die struktureringsbeginsel in 1:1-13}

Die proloog begin met ' $n$ verwysing na die pre-eksistente Logos $(1: 1)$ wat van die begin af by God was (1:2). Alles is deur die Logos geskep (1:3), waarmee die volgende historiese fase (die totstandkoming van die skepping) belig word. In 1:4-5 word van die lewe wat die lig van die mense was, vertel. Hierdie lig het in die duisternis geskyn, wat dit nie begryp/oorweldig het nie. Juis hier lê ' $n$ interpretasieprobleem. Die vraag is of die inkarnasie reeds in hierdie verse ter sprake kom en of dit eerder om die Logos asarkos en dus die algemene openbaringsperiode gaan. 


\section{Joharnes 1:1-18}

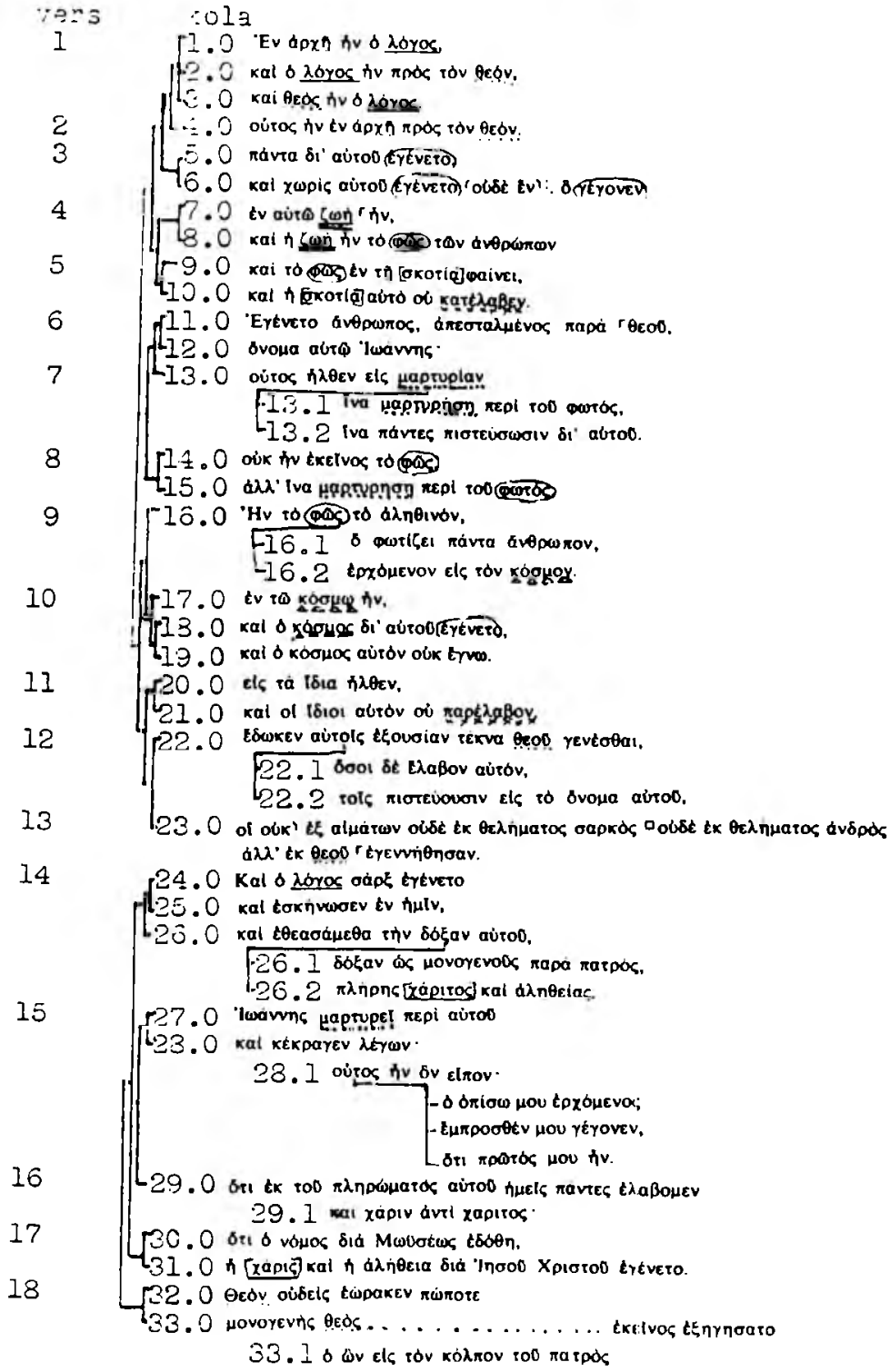

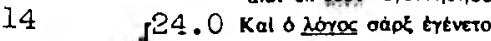

2. 25.0 kal toknwarev tv hulv.

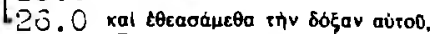

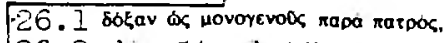

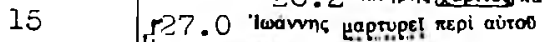

L3.0 kal кécparev htyav. 28. 1 oưtos hv 6v cliov. 
Daar sal gepoog word om aan te toon dat laasgenoemde eksegeties die waarskynlikste keuse is ${ }^{16)}$ (en dat die keuse dus nie o.g.v. strukturele dwang geneem word nie, maar o.g.v. eksegetiese getuienis).

' $n$ Standpunt wat in die relevante literatuur aangetref word, is dat die inkarnasie (en dus die Logos ensarkos) reeds in die eerste vyf verse ter sprake kom. ${ }^{17}$ ) Daar is egter twee direkte verwysings na die inkarnasie in die himne ( $v v .9$ en 14) wat "verskuilde" verwysings na die inkarnasie (in die eerste vyf verse) onwaarskynlik of ten minste moeilik verklaarbaar maak, veral in 'n sterk pre-inkarnatiewe konteks. Juis omdat daar geen duidelike of direkte verwysing na die inkarnasie in die vroeë verse aangetref word nie, berus die onus by diegene wat hier wel inkarnasieverwysings wil raaksien om hul saak te bewys. Indien geen oortuigende argumente in die rigting aangebied kan word nie, lyk die keuse ten gunste van 'n pre-inkarnatiewe verwysing aangewese. Daarom sal van die vernaamste argumente ten gunste van die inkarnasie oftewel die Logos ensarkos in 1:3-5 kortliks bespreek word, ten einde die gewig van die argumente te probeer weeg.

Miller het in die laaste aantal jare as groot kampvegter vir dié standpunt na vore getree. ${ }^{18)} \mathrm{Hy}$ lees die ho gegonen in v.3c saam met v.4 en beweer dan dat die kombinasie na die inkarnasie verwys. Enkele van sy argumente is soos volg:

(a) Die intransitiewe gebruik van ginomai (vv.3c-4) is om te "gebeur", wat dan met die inkarnasiegebeure verband hou. Afgesien van die tekskritiese probleme by die oorgang tussen vv.3c-4, is die interpretasie van die gedeelte geensins 'n uitgemaakte saak nie. Dit beteken dat die werkwoord na ander gebeure lo.a. die skepping) ook kan verwys. ${ }^{19}$ ) Vir die interpretasie om enigsins oortuigend te wees, is meer kontekstuele aanduidings in die betrokke rigting nodig.

(b) Die terme "lig en lewe" word elders t.o.v. die inkarnasie gebruik en daarom is dit volgens Miller ook van dié verse waar. Bultmann argumenteer bv. weer oortuigend dat lewe en lig hier met die algemene openbaring verband hou, ${ }^{201}$ aangesien die werking van die lig ook pre-inkarnatief teenwoordig was. Die feit dat die begrippe elders inkarnatief gebruik word "bewys" nie dat dit hier ook so móét wees nie. Daarvoor verskil die kontekste te veel.

(c) 'n "Los" parallelisme met ander uitdrukkings in die proloog (vgl. vv. $9,14,17$ ) word ook as argument genoem. Uit so ' $n$ "los" (en dus relatief onseker) stylfiguur kan geen dwingende konklusies getrek word nie. 
(d) Hier vind hy teologies reeds die beweging van die algemene skeppingsidee na die besondere soteriologiese idee. Afgesien van die sirkelredenasie hierin vervat, bly die bewys dat dit hier om 'n soteriologiese situasie soortgelyk aan die inkarnatiewe periode gaan, nog uit.

(e) Die gedeelte stem volgens hom met 1 Joh. ooreen. Die werkswyse, om uit 1 Joh, tot ' $n$ bepaalde interpretasie vir Joh. 1 te konkludeer, moet ernstig bevraagteken word. Afgesien van die feit dat 1 Joh. waarskynlik later en met ' $n$ ander doel geskryf is, is daar ook bepaalde eksegetiese argumente wat so ' $n$ een-tot-een koppeling twyfelagtig maak. Daaraan sal hier nie verdere aandag gegee word nie. ${ }^{211}$

Miller noem nog enkele grammatiese en aspektiese argumente waarop nie eens ingegaan hoef te word nie. Uit die oorweging van sy argumente is dit meer as duidelik dat Miller nog veel meer sal moet bied om enigsins ' $n$ oortuigende standpunt daar te stel.

Du Toit wil ook in die eerste paar verse inkarnatiewe klanke laat hoor. ${ }^{22)}$ Hy noem drie redes waarom v.5 wel na die inkarnasie kan verwys.

(a) "Eerstens dui die praesens fainei op 'n herhaling wat nog steeds voortgaan en dit sou dus eerder op die tyd vanaf die inkarnasie tot op die skrywer se hede dui as op die verpligtende werking van die Logos asarkos". ${ }^{231}$ Hierdie aspektiese redenasie moet met versigtigheid hanteer word. Kenmerkend van himnes word daar maklik van die normale aspektiese konfensie afgewyk. Let byvoorbeeld op die gebruik van die aoristus in 1:1 en 1:14, waar dieselfde gebeure wat Du Toit in 1:5 terugvind, beskryf word. Dat die eksterne perspektief sonder duratiewe merking, wat eie aan die aoristus is, nie hier volgens konvensie "pas" nie, lyk duidelik. Immers, die res van die Evangelie handel oor die "tentopslaan" (v. 14) van Jesus wat die gebruik van die aoristus hier verrassend maak. Aspekties sou die praesens hier verwag word. Die aspek in himnes wyk dikwels van die verwagte patroon af wat die verklaring van die werkwoord meer van die konteks afhanklik maak. Daarmee word nie gesê dat die aspektiese funksies hier totaal geïgnoreer moet word nie, maar word alleen tot versigtigheid gemaan wanneer daar in himnes argumente o.g.v. aspek gebou word. Bowendien sou daar vanuit aspektiese oorwegings (die praesens beskryf gebeure in hul verloop) net so goed geargumenteer kon word dat die praesens op die 
periode vanaf die skepping (wat ook in die direkte konteks ter sprake is) slaan. Daar kan gesê word dat die Logos geskep het (v.3), dat die lewegewensbeginsel in Hom was en dat juis hierdie lewe die lig vir die mense was (v.4). Die lig was nie verborge nie, maar het geskyn - van die skepping af toe die Logos die lewe in Hom gehad het (soos die konteks sê). Juis hierdie lig wat van die begin af skyn, kom in 1:9 aarde toe. Dit begin nie eers funksioneer (skyn) as dit aarde toe kom nie, maar skyn reeds van die skepping af.

(b) Du Toit se tweede rede word sonder argument gestel: "Tweedens wys die ontmoeting tussen lig en duisternis eerder op die tyd van die inkarnasie". ${ }^{24}$ "Myns insiens is dit ' $n$ ongegronde stelling. As daarmee na die klimaktiese kulminasie van die ontmoeting verwys word, is die stelling korrek, maar nie oor die algemeen soos dit in die aanhaling gestel word nie. Daar kan op gelet word dat die periode voor die inkarnasie ook wye aandag in die Evangelie geniet. Die positiewe werking van God in die periode word belig. (Vgl. die verwysing na die Wet in 1:17; die sinspeling op die Joodse reinigingsgebruike in 2:1vv en hul godsdiens in 2:16vv; 4:21vv; $5: 46 v v, 7: 19,8: 56$ om maar enkele gevalle te noem. Daar was nie "niks" voor die inkarnasie nie en alles wat daar was, was ook nie sonder die lig of net in duisternis nie). Teologies sou daar geargumenteer kon word dat die lig in vv. $4-5$ verband hou met God se positiewe werkende teenwoordigheid op aarde (vgl. 3:19-21). Dit sou dan beteken dat die verwysing na die pre-inkarnatiewe periode in 1:4-5 in die res van die Evangelie weerklank vind (soos ook die geval met ander belangrike temas in die proloog is). Die verwysing in 1:5 na die duisternis kan moontlik op die sondeval ${ }^{25}$ ) of ten minste op die teenwoordigheid van die bose in die skepping slaan. Die sondige situasie wat in die res van die Evangelie veronderstel word, sal dan so verklaar word. Dit sou ook eienaardig wees indien die Doper se aankondiging (van wegbereiding) eers na die inkarnasie met die effek daarvan genoem en bespreek sou word. ${ }^{26)}$

(c) "En derdens moet die ou katélaben tog eerder as 'n natuurlike parallel vir ouk egno (v.10) en ou parélabon (v.13 - sic) beskou word". ${ }^{27)}$ Hierdie stilistiese argument kan ten beste alleen ondersteunend wees indien daar ander dwingende redes aangevoer kan word waarom die gedeelte as inkarnatief verstaan moet word. Nie een van die reeds bespreekte argumente besit m.i. die vereiste dwingende oortuigingskrag nie. 
Om tot ' $n$ konklusie te kom, kan gesê word dat die argumente ten gunste van ' $n$ inkarnatiewe verwysing in 1:5 op die stadium nog oortuigingskrag kortkom. Die belangrikheid hiervan setel daarin dat, soos reeds genoem, die onus by die voorstanders van die opinie berus om hul saak te bewys, aangesien hulle 'n "verskuilde" en "indirekte" verwysing na die inkarnasie wil postuleer. Die meer aanvaarbare en interpretatief veiliger weg lyk dus om nie die moontlikheid van 'n verwysing na die inkarnasie in 1:4-5 te ver te voer nie. Volgens eksegetiese getuienis lyk dit op die stadium of daar met veiligheid ten opsigte van 1:4-5 van pre-inkarnatiewe gebeure gepraat kan word.

Indien nou teruggekeer word na die argument rondom die historiese verloop lyk die ontwikkeling soos volg: Verse $1-2$ gaan oor die preeksistensie; 1:3 oor die skepping; $1: 4-5$ oor die periode voor die inkarnasie; $1: 6-8$ oor Johannes die Doper se aankondiging; $1: 9-13$ oor Jesus se koms en optrede op aarde met die gepaardgaande resultate. Uit hierdie uiteensetting blyk die kronologies-historiese verloop duidelik. Skematies kan dit so voorgestel word:

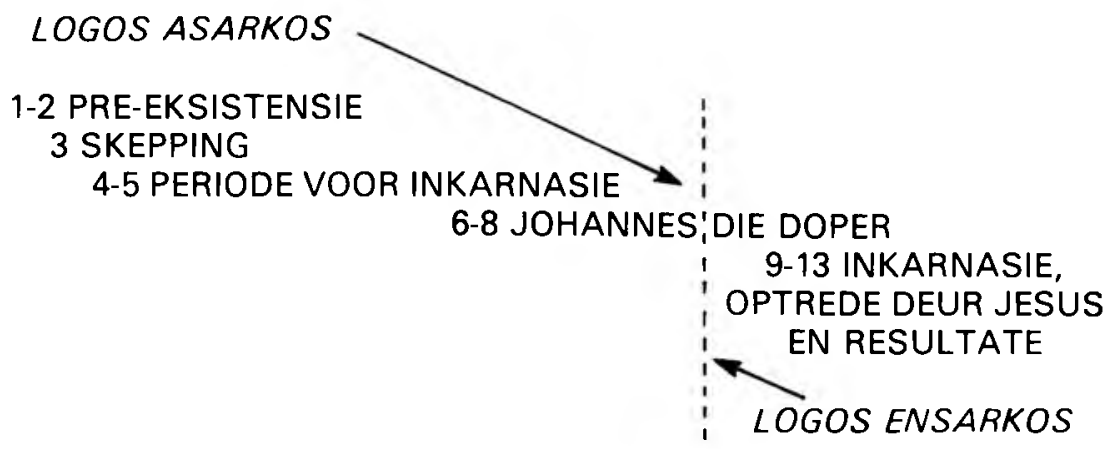

Hierdie historiese verloop moet dan ook as die struktureringsbeginsel van die eerste 13 verse gesien word. Die histories belangrike gebeure of momente rondom die Logos word kronologies aangebied. ${ }^{28}$ )

Om die argument verder te substansieer kan daar op die tematiese sentraliteit van 1:9-13 ten opsigte van die res van die Evangelieboodskap gewys word. By die eerste deurlees van die Evangelie val die motief van aanvaarding of verwerping van Jesus as absoluut sentraal op. By nadere ondersoek word die inisiële indruk bevestig. In sy omvattende studie kom Culpepper tereg tot die volgende slotsom: "Plot develop- 
ment in John, then, is a matter of how Jesus' identity comes to be recognized and how it fails to be recognized", ${ }^{29)}$ natuurlik met die nodige gevolge. In 1:9-13 vorm dit juis die tema. Let byvoorbeeld op die Lig wat kom maar sy eie (idia) wil Hom nie ontvang nie (ou parélabon); die wat Hom tog ontvang (élabon), ontvang die gepaardgaande resultate. Daar kan gesê word dat hierdie verse Jesus se optrede, soos dit in die Evangelie beskryf word, in ' $n$ neutedop saamvat. ${ }^{30)}$ Juis hierdie feit is van belang vir die argument dat 1:1-13 om die histories-kronologiese verloop handel. Soos gesien, word die historiese optrede van Jesus in die res van die Evangelie vanuit ' $n$ bepaalde perspektief geskets en dit is juis hierdie sentrale elemente van die "plot development" wat in 1:9-13 so treffend weergegee word. Dit wil dus voorkom of 1:9-13 nie maar los opmerkings is nie, maar die historiese situasie van Jesus se optrede en gevolglike resultate daarvan samevattend en gestruktureerd wil aanbied. So kulmineer die histories-kronologiese beskrywing in 1:1-13 in die optrede van Jesus soos dit ook in die res van die Evangelie beskryf word. In 1:1-13 word die terrein vir die beskrywings wat in die res van die Evangelie volg, dan ook voorberei en in behoorlike (historiese) perspektief geplaas.

\subsection{Tematies-parallelistiese verloop van 1:14-18}

Wat in die gedeelte opval is die besonder interessante tematiese verloop wat parallelisties opgebou is. Daarop sal nou gelet word.

Die eerste "eenheid" word in 1:14 (kola 24-26) aangetref. In kola 24. 25 word die inkarnasie in konkrete terme geskilder. Dit handel oor 'n histories-aardse gebeurtenis (vgl. sàrks, eskénosen). In kolon 26 verander die trant tematies. Die histories-aardse gebeurtenis word in verband gebring met goddelike kwaliteite soos heerlikheid, genade en waarheid, wat as die gevolg/resultaat van die inkarnasie geskets word. Die goddelike dimensie wat in die inkarnasie teenwoordig geraak het, word dus so uitgedruk. Om hieruit tot tematiese strukturering te kom, sou gesê kon word dat histories-aardse gebeure direk in verband met goddelike kwaliteite gebring word. Dus:

$\begin{array}{lll}\begin{array}{l}\text { Jesus se inkarnasie } \\ \text { i.v.m. }\end{array} & \rightarrow & \text { histories-aards } \\ \text { genade en waarheid } & \rightarrow & \text { goddelik kwalitatief }\end{array}$

Word die tweede "eenheid" (vv. 15-6; kola 27-29) ondersoek, val dit op dat die "patroon" herhaal word. In 1:15 (kola 27-29) word daar na die histories-aardse optrede van Johannes die Doper verwys. Die 
besondere saak waaroor hy in die Evangelie opgeneem word $\mathrm{nl}$. sy getuienis (vgl. marturei, kékragen) word beklemtoon (vgl. kolon 28). In $1: 16$ (kolon 29) word die rede en begronding vir die getuienis gegee en dit word in terme van die volheid en genade van Jesus gedoen. Dit wat hierdie Jesus bring, oortref op 'n goddelike wyse dit wat Johannes die Doper gehad het. Daarom kon laasgenoemde maar net getuig. Hier word die histories-aardse optrede dus weer eens in verband gebring met die goddelike kwaliteite wat Jesus bring, hoewel dit relasioneel in 'n ander verband tot mekaar staan as wat in 1:14 die geval was. Dus:

Johannes die Doper se getuienis $\quad-\quad$ histories-aards
i.v.m.
volheid, genade

Ook die derde "eenheid" (v.17; kola 30-31) vertoon 'n soortgelyke verloop. Die histories-aardse Moses met sy wet, word in kolon 30 genoem. In kolon 31 word die wet (en Moses) gekontrasteer met dieselfde goddelike kwaliteite van genade en waarheid wat deur Jesus gekom het. Dus:

\begin{tabular}{|c|c|c|}
\hline $\begin{array}{l}\text { Moses se wet } \\
\text { teenoor } \\
\text { genade en waarheid }\end{array}$ & & $\begin{array}{l}\text { histories-aards } \\
\text { goddelike kwaliteite }\end{array}$ \\
\hline
\end{tabular}

Vers 18 (kola $32-33$ ) trek die oorkoepelende verband. Hierdie goddelike kwaliteite wat histories-aards deur Jesus teenwoordig gestel word en Johannes die Doper alleen tot ' $n$ ooggetuie maak en 'n geweldige intensiteitstoename met die wet van Moses vertoon, is moontlik omdat Jesus God die Vader kom bekendmaak het. Die goddelike wat onsigbaar was (kolon 32), word deur Jesus sigbaar gemaak (kolon 33). Vanuit die goddelike perspektief van die besondere verhouding tussen die Vader en die Seun en die gevolglike openbaringsaktiwiteit van die Seun lexegésatol word die verband tussen die histories belangrike figure en die koms van Jesus beoordeel. Wie 1:18 verstaan, kan dus die verskillende verbande verstaan wat daar getrek is tussen die histories-aardse persone met hul optrede en die goddelike kwaliteite waarmee dit in verband gebring word.

Skematies kan 1:14- 18 dus by wyse van 'n parallelisme so voorgestel word. 
histories-aardse persone en situasies goddelike kwaliteite

k26: genade en waarheid

k27-28: Doper se getuienis o.g.v. k29: volheid en genade

k30: Moses se wet geintensifeer deur k31: genade en waarheid

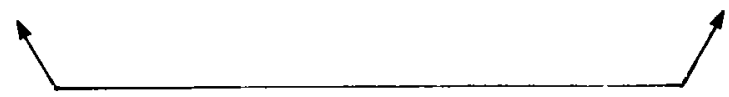

k32 - 33: Jesus openbaar God en verklaar

dus bogenoemde verbande

Daar kan dus gekonkludeer word dat 1:13-18 se konsentrasiepunt val op vername historiese figure (uit belangrike momente in die geskiedenis) en hul verband met die eskatologiese goddelike kwaliteite wat die gevolg van die openbarende koms van Jesus is. Die klem val nie hier op die historiese verloop as sodanig nie, maar op die feit dat die genade en waarheid as bewys dien van ' $n$ voorheen ongekende goddelike dimensie wat in die geskiedenis teenwoordig gemaak is in die persoon van Jesus. In dié opsig verskil die hoof tematiese klem van 1:14-18 en 1:1-13.

\subsection{Die twee dele van die himne chiasties verbind}

Uit wat reeds gesê is, is dit duidelik dat die proloog moontlik uit twee dele (strofes?!) opgebou is. Die struktureringsbeginsel verskil in elke geval. In eg. geval gaan dit om die historiese verloop en in lg. geval om 'n tematies-parallelistiese binding. Word daar egter na die groot aktante of momente waarop die klem gelê word gekyk, val dit op dat daar ' $n$ herhaling in die vorm van 'n chiasme in die twee dele voorkom. Let op die volgende: (vgl. voorstelling op bladsy 80 ).

Daar moet noukeurig op gelet word dat die voorgestelde chiastiese struktuur nie op detailooreenstemming (soos bv. by Culpepper) berus nie. Die onmiskenbare volgorde van die groot figure (en periodes) wat in die twee dele van die proloog ter sprake kom, is struktureel benut. ${ }^{311}$ In die tweede deel (vv. 13-18) was daar duidelik 4 "eenhede" geïdentifiseer wat in omgekeerde volgorde met die eerste deel (vv. 1-13) aangebied word. Die verband is so voor die hand liggend dat hier moeilik van 


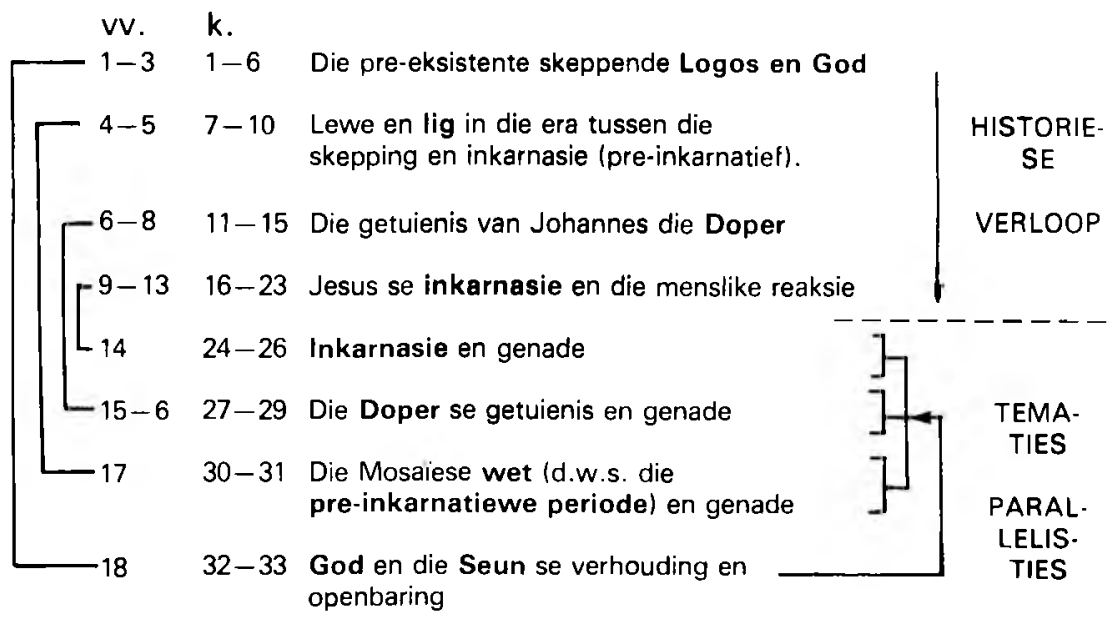

struktuurdwang gepraat kan word. Let byvoorbeeld op die duidelike korrespondensie tussen die twee verwysings na die inkarnasie en Johannes die Doper se optrede respektiewelik. Ten opsigte van 1:4-5 is daar weer breedvoerig probeer aantoon dat dit om die periode tussen skepping en inkarnasie gaan - dieselfde periode as waarin Moses optree. Die lig wat in die periode skyn het 'n bepaalde etiese ondertoon, ${ }^{321}$ wat onder andere blyk uit die "botsing" met die duisternis in 1:5. Hoewel daar dus nie van Moses in 1:4-5 sprake is nie, gaan dit breedweg (histories) om dieselfde periode met dieselfde strekking $(\mathrm{nl}$. lig in die een geval en die wet in die ander). ${ }^{331}$ In 1:1-2 en 1:18 word die verhouding tussen die Vader (God) en die Seun (Logos) geskets en 'n kykie in die preeksistensie gegee, wat sorg vir die korrespondensie tussen die twee gedeeltes.

Die "los chiasme" wat hier voorgestaan word het 'n spesifieke ander doel. Daar is betoog dat die twee dele (vv. 1-13 en 14-18) verskil in strukturering, wat hulle dus ook funksioneel onderskei. Die chiasme bind dan die twee dele ordelik saam en onderstreep die feit dat dit om dieselfde groot sake gaan, maar vanuit verskillende perspektiewe. Daar het histories-kronologies iets gebeur ( $v v .1-13$ ) wat inderdaad op goddelike vlak ongekende dimensies geopen het en wat aan die geskiedenis 'n nuwe genade-inhoud gegee het ( $v v .14-18$ ). Tussen die historiese en die teenwoordigheid van die goddelike genade en waarheid is daar ' $n$ onmiskenbare interaksie. Die skrywer beklemtoon dit juis op 'n meesterlike wyse in die proloog deur struktureel die historiese in die eerste deel te 
belig, die unieke en ongekende teenwoordigheid van die goddelike genade in die tweede deel te beklemtoon, maar tog die onderlinge verband tussen geskiedenis en goddelike genade wat in die persoon van Jesus ' $n$ werklikheid geword het, struktureel te bevestig by wyse van ' $n$ chiasme. ${ }^{34)}$

\section{Konklusie}

In die artikel is daar gepoog om weg te beweeg van die gedagte van een enkele struktuur vir die hele proloog. ' $n$ Poging is aangewend om te toon dat die proloog uit twee dele (strofes) bestaan wat afsonderlik gestruktureer is volgens uiteenlopende beginsels, maar dat afgesien daarvan daar tog ' $n$ oorkoepelende, samebindende struktuur aan te dui is.

Die implikasies hiervan is natuurlik dat dieselfde groot temas vanuit twee perspektiewe ('n meer historiese en 'n meer goddelik-kwalitatiewe) benader is. Deur die fokuspunte van die twee gedeeltes raak te sien, word die leser in staat gestel om die semantiese diepte van die proloog meer effektief te peil deurdat dit wat bymekaar hoort (bv. vv.14-18) eers in eie verband (d.w.s. vv.14-18 in die lig van sy besondere strukturele verband) en dan in breër verband (d.w.s. ook in die lig van vv. $1-13$ en later nog breër) gelees kan word. Detailvrae, soos waarom twee inkarnasies of twee Johannes die Doper-gedeeltes in die proloog aangetref word, word hierdeur ondervang. Die benadering wat ' $n$ basiese eenheidsverband in die proloog voorstaan kan ook as alternatief dien vir 'n oordrewe bronnekritiek van die proloog.

Die voorgestelde strukturele benadering het ook implikasies vir die sg. "sentrale" punt van die proloog wat deur verskillende geleerdes op verskillende plekke geplaas word, maar gewoonlik so tussen 1:12 en 1:14. ${ }^{35)}$ Uit die bespreekte struktuur blyk dit dat die "sentrale tema" nie in een vers of $\sin$ in die proloog vasgepen moet word nie. Die boodskap is veel meer komprehensief as dit. Die boodskap van die proloog is vervleg in die twee afsonderlike dele waaruit dit duidelik word dat die preeksistente Logos in die geskiedenis ingebreek het om die ongekende goddelike genade en waarheid sigbaar en verlossend aan die wêreld te kom openbaar.

\section{NOTAS}

1. Om maar enkele resente besprekings uit verskillende hoeke te noem. $R$ A Culpepper, "The pivot of John's prologue", NTS vol. 27(1981), 1v; P Hofrichter, "'Egeneto anthropos'. Text und Zusätze im Johannesprolog", ZNW vol. 70(1979), 214vv; J Painter, "Christology and the Fourth Gospel. A study of the prologue", ABR vol. 
31(1983), 52vv; J Becker, "Ich bin die Auferstehung und das Leben. Eine Skizze der johanneischen Christologie", ThZ vol. 39(1983), 140v; E D Freed, "Theological prelude to the prologue of John's Gospel", SJTh vol. 32(1979), 257vv; C H Giblin, "Two complementary titerary structures in John 1:1-18", JBL vol. 104(1985), 87vv.

2. Culpepper, NTS vol. 27(1981), 1w.

3. Enkele eksponente van chiastiese benaderings wat nie gedetailleerd behandel gaan word nie, is soos volg: P Borgen, "Logos was the true light. Contributions to the interpretation of the Prologue of John". NT vol. 14(1972), 117v konkludeer o.g.v. wat hy die "Targumic character" van die proloog noem tot 'n basiese chiastiese patroon. Soos ook uit $P$ Borgen se "Observations on the Targumic character of the Prologue of John", NTS vol. 16(1969-70), 291 blyk, kom hy tot die gevolgtrekking o.g.v. die gebruik van sekere sleutelwoorde. M Hooker, "John the Baptist and the Johannine Prologue", NTS vol. 16(1969-70), 356v erken ook in 'n sekere mate die gebruik van 'n chiasme. Volgens haar moet die proloog in twee gedeel word met die Doper-gedeeltes as die "turning-points of the two sections". Ook C H Giblin, JBL vol. 104(1985), 93v praat van ' $n$ implisiete chiasme in die proloog $\mathrm{nl}$. $\mathrm{A}(1-2)$, $B(3-5), C(10-11), C 1(12), B 1(14,16-7), A 1(18)$. Hy is egter versigtig om dit te rigied toe te pas. ' $n$ Meer kru voorbeeld van 'n chiasme word by P F Ellis, The Genius of John, Collegeville 1984, 20 en 27v aangetref.

4. R E Brown, The Gospel according to John. (i-xii), London 1971, 23.

5. Culpepper, a.w., 10vv.

6. 'n Meer volledige bespreking hiervan word in $\mathrm{J} \mathrm{G}$ van der Watt, Ewige lewe in die Evangelie volgens Johannes, Universiteit van Pretoria 1986, 62v gevind. As enkele voorbeeld kan genoem word dat Culpepper bv. op p. 12 van sy artikel "grace (eternal life)" saam noem as synde sinonieme.

7. Van der Watt, a.w., 725vv en 936, punt 69. Eintlik is daar geen plek in die Evangelie waar genade en lewe direk in 'n onmiddellike konteks nou met mekaar in verband gebring word nie.

8. P Ellingworth, "Exegetical presuppositions in translation", BiTr vol. 33(1982), 327.

9. Ed. L Miller, "The logic of the Logos hymn: a new view", NTS vol. 29(1983), 552; Giblin, JBL vol. 104(1985), 94 kritiseer Culpepper se chiasme as synde te gefragmenteerd.

10. W Schmithals, "Der Prolog des Johannesevangeliums", ZNW vol. 70(1979), 31.

11. A B du Toit, "The incarnate Word - a study of John 1:14", The Christ of John. Neotestamentica vol. 2(1971), 15.

12. Brown, a.w., 22.

13. Miller, NTS vol. 29(1983), 552vv.

14. By wyse van 'n kantaantekening kan hier net op enkele van die wyses waarop tekste al gestruktureer is, gewys word. Die oorkoepelende of gemeenskaplike oortuiging is dat die individuele elemente van ' $n$ teks met mekaar saamhang (in relasie staan) en dat die geheel meer is as maar net die somtotaal van die individuele dele. Die relasies word egter op wyd uiteenlopende wyses beskryf. Op die vraag na die "hoe" word 'n wye verskeidenheid struktureringsbeginsels aangebied. So bepaal sg. "foregrounding" Mukarovsky, die Tsjeggiese strukturalis, se benadering, met die gevolg dat hy struktuur met 'n biologiese organisme vergelyk wat voortdurend verander; Propp gebruik die funksies van ' $n$ verhaal; Barthes, as eksponent van die Franse strukturalisme, bring binêre antropologiese relasies in aanmerking; die eksponente van die Amerikaanse New Criticism werk met kohesie, samehang en integrasie op sintaktiese en semantiese vlak; die Merlyngroep kom na aan ons eie struktuuranalise deur die teks fyn te lees op soek na die unieke samehang - verskeie elemente word in die 
analise verreken, soos dit in die teks na vore tree; die Nouvelle Critique het weer op die strukturering vanuit verskillende hoeke bv. sosiologie of psigologie gewys. So kan voortgegaan word om voorbeelde op te noem. Wat hierin van belang is, is dat besef moet word dat daar nie net een struktuur of struktureringsbeginsel is wat algemeen geldig is nie. Die sukses van enige poging tot strukturering is in ' $n$ groot mate afhanklik van die duidelikheid waarmee struktureringsbeginsels wat in die analise van 'n teks benut word (en wat in verskillende tekste ook wyd uiteenlopend kan wees) beskryl word.

15. Du Toit, Neotestamentica vol. 2(1971); Giblin, JBL vol. 104(1985); Becker, ThZ vol. 39(1983).

16. Brown, a.w., 26v; R L Twomey, "Substantial life in John 1:4", AEcR vol. 134, $324 \mathrm{vv}$; J G van der Watt, "A new look at John 5:25-29 in the light of the use of the term 'eternal life' in the Gospel according to John", Neotestamentica vol. 19(1985), $71 \mathrm{vv}$; J Painter, "Christology and the history of the Johannine community in the prologue of the Fourth Gospel", NTS vol. 30(1984), 460vv; F Hahn, Voorlesings oor die uitleg van die proloog, Evangelies-teologiese Fakulteit, Universiteit van München (Wintersemester 1981-82).

17. Hier kan na enkele geleerdes verwys word. M.i. 'n ekstreme standpunt is dié van Ellingworth, BiTr vol. 33(1982), 327 wat meen dat die inkarnasie reeds in vv. 1 tot 3 ter sprake kom. Dit wil voorkom of daar by hom ' $n$ bietjie onsekerheid bestaan oor wat inkarnasie presies is. Giblin, $J B L$ vol. 104(1985), 90 wil die gedagte van inkarnasie metafories in w. $3 c-4$ raaksien. Eksegeties is dit egter nie ' $n$ oortuigende argument nie, omdat die tekstuele aanduidings dat die gedeelte metafories verstaan moet word ontbreek. Giblin gaan self ook nie intensief op die saak in nie.

18. Vgl. bv. Miller, NTS vol. 29(1983), 552-61; Ed. L Miller, "Codex Bezae on John i.3-4. One dot or two?", ThZ vol. 32(1976), 269-71; Ed. L Miller, "The New International Version on the Prologue of John", HThR vol. 72(1979), 307-11; Ed. L Miller. "The Logos of God", EvQ vol, 53(1981), 65-77.

19. Vgl. F F Bruce, The Gospel of John, Grand Rapids 1983, 32v; R Bultmann, Das Evangelium des Johannes, Göttingen 1978, 21v; Brown, a.w., 1971, 6vv; e.a.

20. Bultmann, a.w., 1978, 24vv; Vgl. ook Brown, a.w., 1971, 7v; R Schnackenburg, The Gospel according to St John vol. 1, New York 1968, 242 en 245 verkies ook die onbeperkte werking van die lig voor die inkarnasie as die beter opsie.

21. Vgl. S S Smalley, 123 John, Waco 1984, 4vv.

22. A B du Toit, "Marturia in Johannes 1", Skrif en Kerk vol. 6(1985), 119; vgl. ook Du Toit se ouer artikel in Neotestamentica vol. 2(1971), 16.

23. Du Toit, Skrif en Kerk vol. 6(1985), 119.

24. Du Toit, Skrif en Kerk vol. 6(1985), 119.

25. Brown, a.w., 27.

26. Brown, a.w., 26.

27. Du Toit, Skrif en Kerk vol. 6(1985), 119.

28. Twee opmerkings moet hier gemaak word. i) Die vraag of die historieskronologiese verloop van die gebeure van 'n verheal as struktureringsbeginsel kan dien, moet positief beantwoord word. Uit die ekstensiewe navorsing op narratologiese gebied het die onderskeid tussen bv. die "storie" en "plot" na vore getree wat die bewuste keuse van die verteller in die ordening van sy verhaal onderstreep. Dit impliseer strukturering van die kant van die verteller wat die benutting daarvan as struktureringsbeginsel moontlik maak. ii) Weens die aard van die proloog as himne is dit natuurlik ook moontlik om benewens die groter strukturele raamwerk (wat in die artikel belig word) kleiner individuele stylstrukture aan te wys. Die sg. "staircase parallelism" - Van der Watt, a.w., 1986, 81 voetnoot 30, gee 'n bespreking hiervan 
- in vv. $1-5$ is 'n goeie voorbeeld. In die lig van die voorgestelde historiese verloop as struktureringsbeginsel sou die kleiner stylfiguur ondersteunend kon dien om juis op die vloei van die historiese gebeure te dui. Dit is ' $n$ proses wat beide voortgaan en onderling verband hou. Vanweë die ruimtebeperking van die artikel kon nie verder op die kleiner ondersteunende stylfigure ingegaan word nie. Met die enkele verwysing daarna as voorbeeld is die hoop dat die leser bedag sal wees op die "kleiner" stylfigure en ook sal verstaan hoe hul funksionering binne die groter geheel gesien kan word.

29. R A Culpepper, Anatomy of the Fourth Gospel. A study in literary design, Philadelphia $1983,88$.

30. Dit was baie algemeen in die antieke tyd om die inhoud van die res van die geskrif op een of ander wyse in die inleidende deel weer te gee. Aristoteles (Rhet. 3.14) het dit o.a. een van die vernaamste eienskappe van 'n goeie inleiding genoem.

31. Die proloog is tematies swaar gelaai, wat fyn detailanalise bemoeilik, omdat dieselfde temas en woorde soveel keer en op soveel plekke herhaal word. Daarom lyk die voorgestelde "breë" chiasme vir my meer aanvaarbaar, aangesien dit tot 'n groot mate deursigtig is. Indien die groot figure (en periodes) as basis geneem word, word motivering feitlik oorbodig vanweë die eenvoud van die koppeling.

32. Vgl. Van der Watt, a.w., 1986, 83vv vir 'n beredenering rondom die saak, asook verwysings na ander bronne.

33. Daar moet weer op gelet word dat hierdie chiasme nie op dieselfde gedetailleerde wyse as die van bv. Culpepper beoordeel moet word nie. Indien dit die geval sou wees, sou meer motivering inderdaad nodig gewees het. Daarenteen moet die chiasme gesien word vir wat dit is, $\mathrm{nl}$. ' $n$ verbinding van groot historiese figure en periodes (soos deur die skrywer vir sy doel gekies is) soos dit in duidelike "eenhede" in die proloog ter sprake gebring is.

34. Daar moet hieruit geensins afgelei word dat die eerste deel net "histories" en die tweede deel net "genade" is nie. Dit gaan hier om die betekenisklem in elke gedeelte.

35. Culpepper, NTS vol. 27(1981) sien bv. v.12b as die draaipunt, terwyl J Becker, "Ich bin die Auferstehung und das Leben. Eine Skizze der johanneischen Christologie", ThZ vol. 39, 138 die sentrale uitspraak in v. 14 sien. Ellis, a.w. , 20 sien $1: 12-3$ as die draaipunt. 